Studia Celtica Posnaniensia, Vol 2 (1), 2017

doi: 10.1515/scp-2017-0001

\title{
LANGUAGE LEARNERS OR NEW SPEAKERS: THE TRANSFER OF THE BRETON DIWAN IMMERSION EDUCATION MODEL TO THE LOWER SORBIAN WITAJ PROJECT
}

\author{
NICOLE DOŁOWY-RYBIŃSKA
}

Institute of Slavic Studies, Polish Academy of Sciences

\begin{abstract}
The paper discusses several aspects of immersion and bilingual education systems in Brittany, France and in Lower Lusatia, Germany. Their role in the process of becoming a new speaker of a minority language is exemplified by the Diwan immersion education model in Brittany and the Witaj project in Lower Lusatia concerning the Sorbian people. Taking into consideration the different sociolinguistic situation of both groups, the level and reasons for language shift, the existing language policy in France and in Germany, both educational models are presented. I analyze some factors that influence the possible success or failure of these two models, such as: the linguistic environments, teaching systems, the roles of teachers, the minority language attitudes of pupils, their language practices, the availability of extracurricular activities in the minority language, and the existence of different types of communities of practice. All these factors influence pupils' language choices and practices. Not all language learners will use a minority language in the future, since it depends on the conscious decision of each person. The distinction between language learners and minority language new speakers can thus be justified.
\end{abstract}

Keywords: immersion education, Breton, Lower Sorbian, language learners, new speakers 


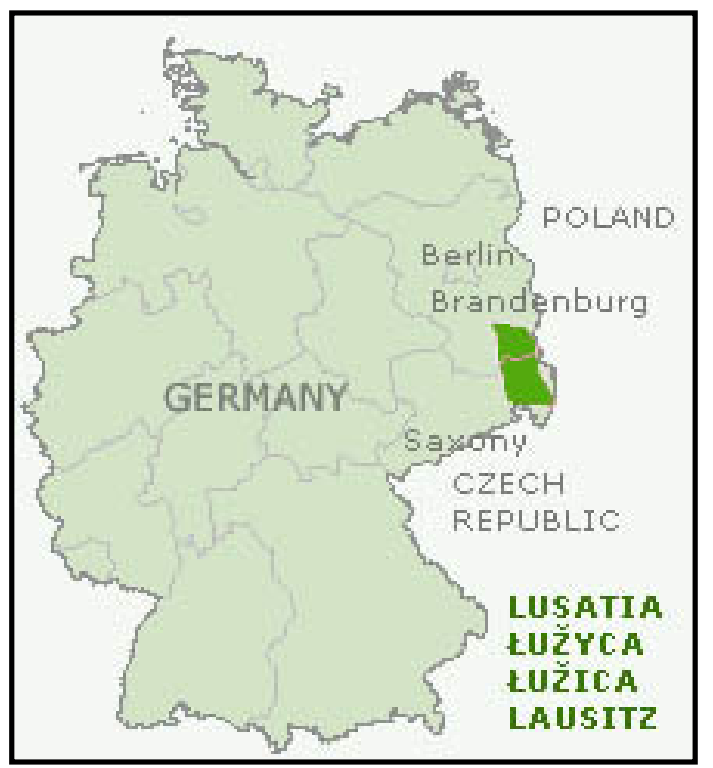

Figure 1: Lusatia in Germany (map)

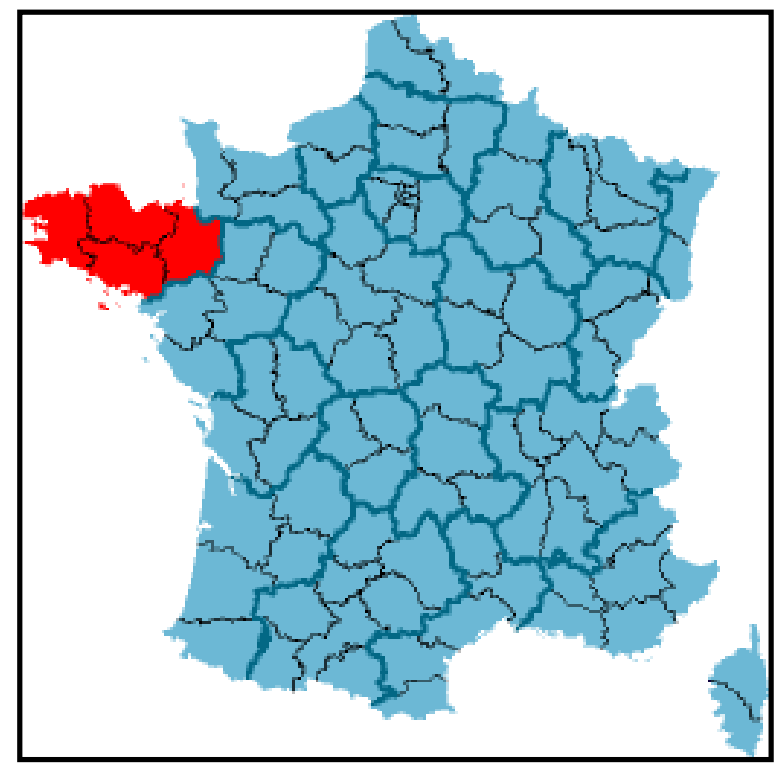

Figure 2: Brittany in France (map) 


\section{Introduction}

The history of bilingual education in Europe is long and has had throughout history different and opposing functions: in some cases it was linked to the linguistic assimilation to the dominant society for children speaking a minority language, in others it served to maintain a minority language. This second task of bilingual or immersion education has been related during approximately the last 50 years to minority languages' revival and revitalization efforts undertaken by minorities such as Basques, Bretons, Welsh, among others. The teaching of a minority language has different forms, starting with a 'weak' form of education that does not lead to bilingualism but to relative or limited monolingualism (monolingualism with some knowledge of another language). Its main form is the additional teaching of a second (minority) language as a foreign language a few hours a week. At the other end of the spectrum are different levels of a 'strong' form of education which are aimed at achieving full bilingualism and biliteracy. The most important forms of this education are bilingual (two-way) education and immersion ones (Skutnabb-Kangas 2000; Backer 2001).

Immersion education may have different methods and levels of intensity, depending on the age of a child, on the time spent in immersion, and on school policy. The immersion system was invented in Quebec, Canada and concerned two major, prestigious languages, English and French (see: Cummins 2009). In Europe, the immersion system has been applied above all in the teaching of endangered minority languages, those lacking prestige and - in many cases lacking societal support due to existing language ideologies. Therefore, it had to deal with different problems and prejudices from both the dominant and minority societies themselves. Adapting the system of one group to another required a number of modalities related to the context of a given culture and language, the degree of language decline, community attitudes toward the language and the education policy of a given region. Sometimes the transfer of the most important properties of immersion education appeared to be impossible. This was the case in the transfer of the Breton immersion education concept to the Lower Sorbian community in Germany.

Although some researchers (Fortune and Tedick 2008) claim that different systems of minority language teaching that they call immersion - such as oneway (foreign language), two-way (bilingual) and immersion - have much in common despite their different contexts, I would not agree with this statement. Different types of education, regardless of their names, lead to diverse forms of language appropriation, different levels of language competences and have a dissimilar influence on the achievements of the cultural capital (Bourdieu 1986) and identity consciousness by pupils. 
The main goal of immersion education among linguistic minorities in Europe is to contribute to the process of reversing language shift (Fishman 1991) that has occurred in many different places across the continent. Most of the children that attend this type of schooling are not raised in the minority language as their first language. Pupils at these schools can be considered minority language learners. In the case of Brittany and Lusatia, their parents decided to send them to schools as an alternative to the public system of education. Most of them - for different reasons - will not continue immersion education throughout all their time at school, from nursery to baccalaureate, but will switch to the formal, state, monolingual one. Some of these immersion education students will never achieve sufficient competence in the minority language to be able to use it in an everyday context (see among others, Harris and Murtagh 1999; Heller 1999; Dołowy-Rybińska 2017). Among those who are able to communicate easily in a minority language there are some who will not live in a minority language environment or who will not identify themselves with the speech community and because of this will refuse to use the minority language. Only a small group of language learners, those who decided to use the language despite unfavorable circumstances, can be called 'new speakers' (see. among others, Costa 2015; Hornsby 2015; O'Rourke, Ramallo and Pujolar 2015). The effectiveness and opportunities offered by different types of minority language education systems play an important role in the process of forming new speakers. In this paper I will present in what manner the Diwan immersion system from Brittany was transferred to Lower Lusatia and how it was changed there. I will also analyze some important aspects of both types of education that facilitate or impede their pupils' transformation from minority language learners to new speakers.

2. The sociolinguistic situation in Brittany and Breton language immersion education

An important sociolinguistic change occurred in Brittany in the second half of the $20^{\text {th }}$ century. After the Second World War the intergenerational transmission of the Breton language had almost totally broken down which resulted in the number of Breton speakers decreasing from 1,100,000 at the beginning of the $20^{\text {th }}$ century to about 200,000 by the end of the $20^{\text {th }}$ century (Broudic 2009). This process was the consequence of the French state's long-term language policy directed against minority languages within the Republic. Breton, associated with rural life and a lack of education, had a low prestige value and was further reduced by different types of harassment and symbolic or physical punishment for using the Breton language in public life, including schools, 
offices, and the army. Industrialization and urbanization as well as the appearance of the mass media accelerated the process of the decline in the use of the Breton language. Additionally, the occurrence of some episodes of Breton nationalist collaboration with the Nazis during the war influenced people's negative attitudes against the Celtic language. In these circumstances, most Breton-speaking families decided not to use their ancestral language with their children (Elégoët 1978; An Du 2000; Broudic 2013). At the beginning of the $20^{\text {th }}$ century Lower Brittany was almost totally monolingual in Breton. One century later, after the total number of Breton speakers was estimated at less than 200,000 , with about $70 \%$ of this demographic more than 60 years old (Broudic 2009).

This estimated number of Breton speakers includes not only native speakers but also those who have learnt the Breton language during formal or informal education and who began to practice it under different circumstances - so-called néo-bretonnants - new speakers of Breton (Pentecouteau 2002). At the beginning, these people were associated with the Breton movement of the 1970s aimed at the revalorization of the Breton language and culture which was carried out by the generation of Bretons who - in most cases - had not received the language by transmission in the home. Being conscious of the problem of language shift, they concentrated on new transmission methods for the Breton language: through music, art and, of course, education, both for children and for adults. Many different courses were initiated all around Brittany and learning this language was treated by adults as an act of activism (McDonald 1989).

The first immersion Diwan school was opened by Breton activists in 1977 (Perazzi 1998). Starting with 3 nursery school pupils, and facing many institutional (the state did not recognize the initiative) and financial (no state subventions) difficulties (Nicolas 2001: 136), over the last almost 40 years the total number of pupils has increased to $4,242^{1}$ students in all categories of schools (from nursery to high school). At the outset, Diwan schools were run, hosted and organized by Breton language activists (Vetter 2013). These were associative schools which involved the engagement of the pupils' parents in the functioning of these schools. However, in the unfavorable minority language sociolinguistic situation, the decision to educate children in immersion Bretononly schools, was difficult for parents. Nonetheless, the teaching level and results from the Diwan $l_{i s}^{2}$ for the baccalaureate supported the parents' choices but also changed its activist nature (Goalabre 2011).

All figures concerning Breton from: Office Public de la Langue Bretonne, http://www.fr.brezhoneg.bzh/evenement/1511/50-actualite.htm. Accessed : 13.10.2016.

2 Lise, bret. (Lycée, fr.) - a school of secondary education in France for teenagers aged 15-18. 
Apart from immersion schools where the minority language is considered the medium of education and in all contact between pupils, teachers and school personnel (Hinton 2001), there are also bilingual schools, Div Yezh ('Two languages, bilingual', in Breton), created in 1982 with more than 7,217 children in 2016. Some of the subjects in these public bilingual schools are taught in the Breton language, although the intensity and quality of the Breton language depends on the policy of a particular school. Since 1990 the Breton language has also been taught as a subject/foreign language a few hours per week in private, Catholic Dihun ('Awakening') schools (with 5,219 pupils in 2016).

The education system in all three types of school is thus different, starting with the 'weak' form of education which does not lead to bilingualism but serves only to introduce the minority language to pupils (Skutnabb-Kangas 2000); through to bilingual schools that give pupils a chance to see that every subject can be conducted in the minority language (which increases its prestige) but often do not give pupils the opportunity to become comfortable with the everyday use of this language; to the 'strong' form of education which is targeted at providing full bilingualism both to children who belong to the linguistic minority and those who come from monolingual or linguistically assimilated families. The Diwan school should play this role but - as I will describe in section 4 - the reality is not that straightforward.

3. The Lower Sorbian sociolinguistic situation and the transfer of the Diwan immersion system to the Witaj project in Lusatia

Lower Sorbian can be classified today as a critically endangered language ${ }^{3}$. Although the latest official statistics (Elle 2000) reveal about 5,000 Lower Sorbian users with most of them belonging to the oldest generation, these numbers date back to the second half of the $1990 \mathrm{~s}$ - more than 20 years ago. Since then these numbers - which certainly do not represent the current situation of the Lower Sorbian language - have not been verified, for various reasons (Elle 2010). The sociolinguistic situation in Lower Lusatia has changed considerably over this 20 -year period and many Lower Sorbian native speakers have died. At the same time new revitalization ideas, including the schools of the Witaj project, have emerged. It is therefore impossible to understand the present problems of Lower Sorbian without closely investigating the reasons for

The UNESCO Atlas of the World's Languages in Danger describes Sorbian as 'definitely endangered' ('children no longer learn the language as mother tongue in the home'). The problem with this classification is that both Upper Sorbian and Lower Sorbian (of different ethnolinguistic vitality) are treated here as one language. http://www.unesco.org/languagesatlas/index.php?hl=en\&page=atlasmap. Accessed 10.05.2017. 
the language shift in Lusatia and the Lower Sorbs' attitudes towards their language and culture.

The Sorbian situation appears to be more complicated because there are two Sorbian minorities and two Sorbian languages being in different sociolinguistic situation. Among Upper Sorbs living close to Bautzen/Budyšin with about 10,000-12,000 language users, there is a quite strong speech community of Catholics. Upper Lusatia historically belonged to Saxony where the assimilation policy was never a priority. In contrast, the Lower Sorbs who had their language codified during the Reformation, and inhabited Prussia, which had a very strong anti-Slavic policy. In addition, all Lower Sorbs converted from Catholicism to Protestantism in the $16^{\text {th }}$ century and this entailed a gradual linguistic assimilation (Dołowy-Rybińska 2011: 271-277). The anti-Sorbian policy in Prussia during the time of the Nazis was also much more vindictive than in Saxony: using the Sorbian language and - most of all - declaring Sorbian identity was dangerous for Lower Sorbs. Important language change occurred in Lower Lusatia between 1935 and 1955 (Norbergowa 1997). This was due to industrialization and military service, with the appearance of German-speaking migrants from the new Polish territories who, by settling in Lusatia, changed the linguistic balance of the inhabitants, and of the anti-Sorbian policy before and after WWII. Research by Steenwijk (1999: 444) shows that Lower Sorbs belonging to the oldest generation (the last native speakers of the language) often had negative attitudes toward their language which they perceived as a source of conflict. Only recently have attitudes towards Lower Sorbian begun to change with the start of some revitalization processes.

Political transformation and German reunification of 1990 opened up the possibility of adapting some new concepts to the revitalization of the endangered language in Lusatia. The most urgent, particularly in Lower Lusatia (Land of Brandenburg) where the intergenerational transmission of Lower Sorbian had already been broken for three generations, was a new education system that would allow the creation of new Lower Sorbian speakers. This system formerly in place had been established in Lusatia after WWII and gave the Sorbs the right to learn the Sorbian languages. Nevertheless, this freedom of choice was strictly regulated. Only in Upper Lusatia, schools with Upper Sorbian as the language of instruction existed, while in Lower Lusatia children could only learn Lower Sorbian as a foreign language for two or three hours per week (Pech 2001). Moreover, as it was not approved of by the German-speaking inhabitants of Lower Lusatia and by the government, many Sorbs decided not to send their children to Lower Sorbian lessons. It is also worth mentioning that during the time of the communist regime in Germany, Lower Sorbian was supported by Upper Sorbian activists. This had twofold consequences. Firstly, Upper Sorbs with their much stronger language base were helping Lower Sorbs to maintain 
their language. Secondly, however, there was a constant linguistic influence on the Lower Sorbian language with some attempts to make it more similar to Upper Sorbian (Marti 2014). As a result of this process, Lower Sorbian began to exist in (at least) two forms: a dialectal one and a literary version often treated as 'artificial' by the older generation, similarly to the situation in Brittany (for the ideology of authenticity see: Bucholtz 2003; Bucholtz, Hall 2004; Woolard 2008; O'Rourke 2011; Hornsby 2015).

The idea to transfer and to adapt the immersion model Diwan that exists in Brittany for Lower Lusatia was envisaged by the Sorbian activists at the beginning of the 1990s. The problem was that there were no private or associative schools in the region of Lusatia but all the schools were financed and controlled by the education ministries at the local level (Free State of Saxony for Upper Sorbian and Land of Brandenburg for Lower Sorbian). Only the nursery schooling system was partially private and it was at that basic level that the Lower Sorbian activists decided to concentrate at the beginning. The main difference at this level between the Diwan and Witaj models was that the Breton schools were established in opposition to the state-run system as the grass-root action of Breton activists while in Lower Lusatia ethnic leaders decided to proceed in accordance with the existing system. Another difference was that Diwan pre-schools used full immersion system (everything in Breton) while in most of Lower Sorbian kindergartens only a part-time immersion was possible. This was because in Lower Lusatia there are almost no children who are Sorbian native speakers.

Gradually, the Witaj project in Lower Lusatia increased in primary and secondary schools also but - considering the low numbers of children raised in the Witaj kindergartens as well as other organizational problems - it was not possible to establish Lower Sorbian-only schools. The new legal framework (Norberg 2010) has enabled the introduction of bilingual Lower SorbianGerman education into the Brandenburg schools. Lower Sorbian as one of the languages of instruction is now established in some schools in Lower Lusatia ${ }^{4}$ and in the Lower Sorbian grammar school in Cottbus/Chóśebuz, although not all pupils in these schools are learning within the framework of the Witaj model. Moreover, here we cannot speak about immersion education but on bilingual one. Nevertheless, the number of children who are learning in this way is increasing systematically (Norberg 2010). In academic year 2013-2014 there

The number of children learning Lower Sorbian in Brandenburg has grown from 1,051 in $1994 / 1995$ to 1,731 in $2010 / 2011$. What is more important, from $2004 / 2005$ there are also pupils who are learning in the bilingual system (as a part of the Witaj project). This year, when Witaj project started to function, only 81 pupils (out of 1,601 who were learning Lower Sorbian) were learning bilingually. In 2010 this number increased to 282 pupils learning bilingually (after: Budarjowa 2014: 312). 
were 6 schools which had Lower Sorbian as a medium of instruction according to the Witaj education (bilingual education) and as a foreign language (Mercator European Research Center 2016: 29). The Lower Sorbian Gymnasium ${ }^{5}$ is currently the only grammar school which gives lessons of Lower Sorbian as a subject (for those who did not participate before in the Witaj education) as well as teaching some subjects in Lower Sorbian as the language of instruction (bilingual Witaj education). The comparison between the Diwan immersion system in Brittany and the Witaj project in Lower Lusatia and huge differences between them shows that it is not possible to transfer the full concept to different sociolinguistic situations without having to change priorities. It seems that more similitudes can be found between Witaj project in Brandenburg and Breton bilingual Div Yezh education. This is because full immersion education in the Lower Sorbian condition is not possible. My aim is thus not to devalue any systems by showing their weaknesses but to draw some positive conclusions on how schools can help to reverse (minority) language shift and to contribute to the emergence of new speakers of minority languages.

\section{Factors influencing the success of immersion education - comparison}

The possible success of immersion education depends on many different factors that play important roles. Only one of them is the teaching program and its influence on children's language choices after school ends. This in turn constitutes the main goal of such programs. Factors such as the linguistic environment in the school and in the community can also be important as well as the teacher's predispositions, and the attitudes of the pupils, the members of the community and of the dominant society. Participating in different extracurricular activities and being a part of some communities of practice related to the minority language may influence the linguistic choices of pupils which in turn are responsible for their future language competences and from which they gain the confidence to use it. In this part of the article all these factors will be discussed and a comparison made between the Diwan and Witaj schooling systems.

\subsection{Linguistic environment}

Today the sociolinguistic situation in Brittany is complicated: the older generation of Breton native speakers is declining with the death of its members.

Gymnasium is a type of secondary education school in Germany which prepare pupils to a higher education and finishes with Abitur (baccalaureate) usually at the age of 18 . 
They had no opportunity of learning the Breton literary language at school. They use - only between people they know from their surroundings and in most of cases very discreetly and out of earshot - the dialectal forms of Breton. Many decided not to transmit the language to their children so the middle generations of Bretons have none or just a passive knowledge of the language. Some have decided to learn it by themselves. Those people from the middle generation often belong to the group of Breton activists who fought for their linguistic rights frequently without the support of older Breton native speakers. They usually speak a standardized, pan-Brittany variety of Breton, created in the $20^{\text {th }}$ century (Hornsby 2005). Some have sent their children to the Diwan schools (or other Breton language schools) but only rarely use the Breton language in their family life (Broudic 2009: 137). Breton native and new speakers often claim not to be able to understand each other (see Hornsby 2015; Dołowy-Rybińska 2017). In such a situation - where young people who know Breton constitute only 4\% of the people of Brittany aged 15-19 (Broudic 2009: 66) and it is hard for them to communicate in Breton with the older generations - there are not many possibilities for young people to practise their Breton. That is why for many Diwan pupils the school is one of the few places where Breton is (one of) the language(s) of communication.

When comparing the sociolinguistic situation in Brittany with that of Lower Lusatia, activists thought that, in both cases, the intergenerational transmission had been broken and the new generation did not know the ethnic language. They did not take into consideration the effects of the Breton movement of the 1970s and the existence of new Breton speakers. Research among Diwan pupils shows that about $8 \%$ of the parents of Diwan pupils use Breton between themselves, in $1 \%$ of the families it is only the mother with whom the child can speak Breton and in 17\% only the father (Broudic 2010: 48). Though these numbers are low, there cannot be any comparison, with the Lower Sorbian situation where according to the research (Budar and Norberg 2006: 30) in fact, no child's parents could speak Lower Sorbian. The Witaj project established finally in 1998 had to function in much more difficult sociolinguistic circumstances than the Diwan model.

At the beginning of $20^{\text {th }}$ century, Spiess (2002: 23) mentioned that Lower Sorbian was the native language of a group of people belonging to the oldest generation, born before WWII. People born after the war knew this language only passively as their parents used it while communicating between themselves but in conversations with their children they spoke only German. The younger generations now do not know Lower Sorbian at all. In Brittany, over the last 30 years, we can observe the increase of the presence of the Breton language in the public space (including the mass media, bilingual signs, concerts and artistic events in Breton all around Brittany); however, in Lower Lusatia the presence 
of Sorbian is insignificant and diminishing. Even manifestations of the Lower Sorbian culture - artistic or folkloric events in Lower Lusatia as well as most of Lower Sorbian intelligentsia meetings - are held exclusively or almost exclusively in German ${ }^{6}$.

All these factors influence kindergartens and schools in their linguistic environment. In Diwan, all the teachers and educational staff speak fluent Breton and try to communicate with pupils only in this language. In some schools, there is a lack of Breton-speaking auxiliary personnel (cooks or cleaners) but in many places Diwan schools are trying to hire students or young people who speak Breton as trainees or on a voluntary basis to supervise the children during breaks and after lessons and encourage them to use Breton. In contrast in Lower Lusatia, Lower Sorbian-only kindergartens are rare, and there are no Lower Sorbian schools which function solely in the language. In most schools there is only one Lower Sorbian group in the German only speaking environment (Norberg 2010). Under these circumstances, children raised theoretically in Lower Sorbian hear mainly the German language (which is their first and only language as well as the language of their families). It is the same in schools where pupils who have bilingual education but communicate with most of the teachers, school staff and their peers in the German language only. In this case, it is not possible to speak about a 'strong' form of education which demands full 'immersion' in the minority language environment.

\subsection{Teaching systems}

Currently, there are 41 nursery and primary Diwan schools, six lower secondary schools (collèges) and one lise (higher secondary school). Most of Diwan pupils stop their immersive education at the midpoint of their education and thereafter continue with French language instruction. Obviously, from a language competence perspective this is very unfortunate. The Diwan teaching method in their schools use the same official education program as all French state schools follow. In the nursery and at the beginning of the primary school, only the Breton language is used. The French language is gradually introduced after to pupils but it is the language of instruction for French studies only. Foreign languages are taught in their own languages.

It is very difficult to give the exact numbers of Witaj schools in Lower Lusatia because of two reasons. Firstly, the education system is much more complicated with some nursery schools immersive, others with only one Lower Sorbian group within the German establishment. Secondly, in the case of

6 Although, it should be recognized that this tendency slowly changes in favor of the use of Lower Sorbian. 
schools the situation is even more complex. In some schools, the Witaj project functions in the form of bilingual and not part-immersion education. In some, the Lower Sorbian language is taught within interests groups as the language of interactions or as a foreign language. In the school year 2009/2010 there were 24 primary schools with some Lower Sorbian language classes, two middle schools and one Gymnasium in Cottbus with one added class where learning the Lower Sorbian is obligatory and where some subjects are taught bilingually (Norberg 2010: 68-72). There is no school, though, where the only language of instruction and of school interaction is Lower Sorbian.

\subsection{Teachers}

As already mentioned, when Diwan schools began to function in the 1970s it was the Breton activists, often without any previous training, who became the teachers. They had different backgrounds: some of them were Breton native speakers with no pedagogical training, others were new Breton speakers, and usually politically engaged. The teacher training centre for Diwan schools where future Diwan teachers were trained, the Kelenn Institute, was only created in 1997. During the last few years, with the rapid growth in Diwan school numbers, the need for new teachers has emerged. The regional council subsidizes a six month long intensive course for adults and some of the teachers can become bilingual and therefore able to teach in Breton. It has thus consequences on two levels: on one hand, the number of teachers increases but on the other hand, some of them are not fluent yet in this language and many of them are separated from Breton culture and the Breton movement and as such are not fully engaged in it. This creates in turn a new type of Diwan school teacher, which treats teaching Breton as any other occupation and not as a mission (see more: Dołowy-Rybińska 2017: 119-120; 311-312).

In Lower Lusatia, the situation was much more serious from the beginning: there were no teachers or pre-school minders able to speak Lower Sorbian. To deal with this problem, intensive six month courses for future teachers were instituted (Budar and Norberg 2006: 36). Unfortunately, many new teachers when staring their work were not prepared enough to use Lower Sorbian with the children all the time (Dołowy-Rybińska 2011: 311). In many cases, all that the children in Lower Sorbian nursery schools could hear in Lower Sorbian were some songs or plays but not the living language. From this reason, among others, introducing the Witaj project in schools was not possible. Today the situation is improving slowly as the first years of young people who had bilingual education are studying Sorbian in Leipzig where for the first time there are students specializing in the Lower - and not Upper - Sorbian language. It is also important to mention the role of Upper Sorbs who are 
working in Lower Lusatia, as well as people coming from Poland or Czech Republic to become Lower Sorbian teachers. As they are Slavic-speaking, it is much easier for them to achieve an adequate level in Lower Sorbian than it is for the native German speakers. Nevertheless, the low number and predispositions of Lower Sorbian teachers still represent an important problem to be rectified in Lower Lusatia.

\subsection{Pupils' language attitudes}

The concept itself of language attitudes is complex, as indeed are the methods of assessing them (Garrett, Coupland and Williams 2003; Garrett 2010). It lies at the intersection of many different social sciences domains and demands careful and profound study. There are both the individual language attitudes each person possess and collective language attitudes that depend among others on language prestige, vitality, power, and practices but also on how the language is presented and perceived by both dominant and minority groups. These perceptions are determined by existing language ideologies (Schieffelin, Woolard and Kroskrity 1998; Sallabank 2013). In both cases, Brittany and Lower Lusatia, language ideologies are based on the historical negative image of these languages and their insignificant value in public life. The Breton movement of the 1970s managed to reverse this negative image of the Celtic language to some extent (and in the eyes of a particular group of people) (Delon 2007) but in the case of Lower Sorbian it was not so straightforward.

Nevertheless, the language attitudes of pupils do not depend only on the central language attitudes and ideologies that exist within the major part of society - they are also produced within a smaller community among school pupils, teachers, parents and staff. It is not possible, however, to describe them directly and to give a general image of all Diwan or Witaj pupils' attitudes. I am basing this article mainly on my former research in Brittany (Dołowy-Rybińska 2016, 2017) and Chauffin's research (2015), and the years of participant observation in Lusatia (Dołowy-Rybińska 2011), and the Neumann publication (2014) on the Lower Sorbian Gymnasium in Cottbus.

In the Diwan schools, where the 'one language' rule is strictly adhered to, especially in primary and middle schools, many pupils rebel against it and do not want to use the Breton language. During my fieldwork, I repeatedly heard that, when forced to speak Breton, young people consciously decided to use mainly French (on speakers' conscious decision to speak minority languages, see among others: Dorian 1980; Woolard 2011). However, the general attitudes of Diwan pupils toward the language are very positive: they treat it as a personal distinctive indicator; they declare that they love it and are ready to 
struggle for its future. The fact that Diwan pupils create somewhat quite closed communities (perceived as closed from the outside world) helps pupils to identify with the language even while not using it often enough.

In the schools where the Witaj concept was introduced, pupils do not form a coherent group, as they have to function within a larger society of school pupils, teachers and staff who speak only the German language. They thus have to deal with the language ideologies and attitudes of those who are not associated with the minority language and who are often to some extent negative about the 'dying language' and the Slavic language. As research and observation showed pupils in Lower Lusatia possess differentiate attitudes towards Lower Sorbian: from positive from those who declare their willingness to take more opportunities to learn and to speak Lower Sorbian; through those who are rather indifferent and who treat Lower Sorbian as just another school subject; to those who are negative about it and do not want to be forced to spend the time learning a language with no future and no usefulness. However, and it is important to mention this, in the classes with Lower Sorbian in the Lower Sorbian Gymnasium, the pupils' language attitudes are quite positive and are improving constantly with more new pupils who have passed along the entire Witaj project path (Neumann 2014).

\title{
4.5. Pupils' everyday language practices
}

One of my sixteen year old research participants from the Diwan lise stated:

\begin{abstract}
Normally we are supposed to use [Breton language] here all the time. But we don't do it because with our parents and so on ... there are some who speak with their parents in Breton but we don't. And we are not in the habit of speaking Breton, so we choose French. Even if I like to speak Breton, however it doesn't come just like that, naturally. Well, maybe yes, but I can't imagine speaking Breton just like that.
\end{abstract}

This short citation tells us a great deal of Diwan pupils' language practices. Most pupils are not born into Breton-speaking families. In many cases, Diwan pupils do not live in a Breton-speaking environment. That is why the constant use of Breton is difficult for them. It does not mean that pupils are not using Breton at all outside of classes. For many Diwan pupils, especially studying at the Diwan lise, Breton also plays a very important symbolic role (DołowyRybińska, in press). Much also depends on smaller communities of Diwan pupils and their conscious decision to speak Breton despite all the difficulties. The stronger an individual's decisions to practise Breton are, the more they will influence other people's language choices. That is why language practices in a Diwan lise can differ from one year to another. 
Lower Sorbian pupils find themselves in a different position as almost no one (except the most motivated individuals or those whose parents are engaged in the protection of Lower Sorbian) achieves Lower Sorbian language competence that would enable him/her to use this language even in a casual conversation. Moreover, with no Lower Sorbian-speaking environment and the low level of knowledge of this language among their schoolfellows, the only person they could practise it with are teacher(s) which does not facilitate their language choices. In general, in any Witaj school no Lower Sorbian can be heard outside of dedicated school hours.

\subsection{Extracurricular activities in the minority language}

One of the most important parts of Diwan education is to organize the children's after-school time around Breton language activities. Diwan, as associative schools, function through parents, teachers, staff and NGO commitment, which means that many people, are engaged in the functioning of the school at different levels. Parents and associated groups often organize festoù $n o z^{7}$ to support financially a particular school. While engaged in these events children have the opportunity to speak Breton with people from the wider community, and to be aware of the responsibility for the future of their school and of the Breton language. Proximity and cooperation with different groups and associations also gives the children an opportunity to participate in many artistic, musical and language events and workshops. Chauffin's research shows that $80 \%$ of Diwan pupils participated in artistic - mainly theatre workshops in primary school, they also often went out to engage with Breton language theatre performances or cinema. Among high-school students, 20\% are themselves musicians or singers due primarily to the common practice of festoù noz and related kan ha diskan singing (Chauffin 2016:113). The common practices related to the Breton language are reinforced because lise students live together during the school week in a boarding house.

When we consider Witaj schools in Lower Lusatia and participation in extracurricular activities related to Lower Sorbian, we find that this pattern is not so evident. Although Witaj pupils are engaged in many different cultural events organized around Lower Sorbian culture, most of these events are mainly in the German language. Lower Sorbs are strongly attached to their culture but, because of the language shift that occurred many years ago, they separated the

Festoù-noz (sing. fest-noz), "night festivals", events with dancing in groups and live musicians playing acoustic instruments. They are a part of the Brittany traditional culture and are still cultivated (also as a part of the Breton modern culture). (See: Dołowy-Rybinska 2013). 
folkloric and performative aspects of their culture from the linguistic one. Even some Lower Sorbian songs connected to a specific Lower Sorbian event are sung in German. There are also not many Lower Sorbian events of contemporary culture (concerts, theatre performances, films) proposed for children and young people. This lack is only partially recompensed by some activities for children proposed by the Witaj Language Centre (WitajSprachzentrum/Rěčny centrum Witaj): some mutual artistic events, including theatre performances or Lower Sorbian dubbing for a film, and - from time to time - holiday language camps ${ }^{8}$.

There are also some activities organized by the boarding home of the Lower Sorbian Gymnasium but they are only partially in Lower Sorbian as the pupils' levels are not sufficient for them to speak and understand the language. The function of these activities is thus to sensitize pupils to the language rather than to make them make use of it (Zakar 2016: 66).

Schools where the minority language is being taught, particularly where the minority language is the language of instruction, have an additional function to fulfill along with the teaching of the language itself. They should also pass on the cultural competences which can be acquired through diverse extracurricular activities during which young people are introduced to the minority culture and its problems so that they become interested or even engage in minority life affairs. Obviously, in both cases, Brittany and Lower Lusatia, there are numerous associations, institutions, groups and programs that organize events for children and young people to help them practice their language and to familiarize them with the minority culture. Nevertheless, their role is quite different as they are not directed at the community of pupils but at individuals. Whether young people take part in them depends therefore on their parents, the environment, their peers, etc. but not to the school as an institution.

4.7. The existence of communities of practice associated with the minority language

The community of practice can be defined as "a group of people who share a concern or a passion for something they do and learn how to do it better as they interact regularly" (Wenger-Trayner 2015: 1). The community of practice demands the existence of a common domain that connects the people around it. In the case of a minority language school, the domain is specified by the context that groups the students all together. The second necessary aspect is the

The full list of proposed activities in the Lower Sorbian language can be found here: http://www.witaj-sprachzentrum.de/index.php/hsb/projekty/projekty-dl (accessed 19.10.2016). 
existence of a community that has been created with people who know each other, who meet frequently, and - as connected through a common domain they share opinions, passions and activities. These people learn from one another and exchange information and through this process become more closely related. They will also create a common identity. Not all of the school pupils constitute a community of practice: the fact of being in one building and being taught the same subjects is not enough for a group's identity to be formed. There is also a need for common practice based on participation and engagement in some organized activity. Communities of practice cannot be compared to extracurricular activities although in some cases - when the interaction is long, regular and demands engagement - they can overlap.

This is the case with some theatre and musical groups that exist in the Diwan lise in Carhaix. These groups are not created for just one performance and as the young people work together for a long time they get to know each other and can influence each other's interests and ideas. Some examples how the communities of practice are being created through Diwan schools have already been discussed elsewhere (Dołowy-Rybińska 2016, 2017, in press). Chauffin's (2015) research among ex-Diwan students also proves that the results of this type of participation are long term. When we compare the Diwan lise with the Lower Sorbian Gymnasium from Cottbus, we see that it is really difficult for Lower Sorbs to create from the school base a minority language community of practice. Students often complain that the school does not offer them enough possibilities to practise their language and to become aware of the cultural problems of Sorbs (Neumann 2014). There was some hope in the association "Zapalaki" which existed for a short while (it does not function at present). It was initiated a few years ago by Lower Sorbian Gymnasium students who inspired by their teacher, and disappointed by the lack of opportunities to practise their language and supported by Lower Sorbian students - created a group of new Lower Sorbian speakers. They decided to use only Lower Sorbian between themselves despite all the difficulties they had in doing this. Those who were involved in the group not only became fluent in Lower Sorbian but also some started to become involved in the cultural protection and maintenance of Lower Sorbian. It is rather unfortunate that for the time being the "Zapalaki" group is an exception - important but unique. Although, as Zakar (2016: 68) stated, the interest in Lower Sorbian among young people is growing but it is hard to head an organized association in Lower Lusatia when we consider the small number of Lower Sorbian speakers.

In the Diwan lise, communities of practice - related to artistic, politics or linguistic issues - are common. They are created using existing projects initiated by teachers or additional programs, or by students, through grass-root initiatives brought about through their own needs or inspirations. In the Lower 
Sorbian Gymnasium the Witaj group of students is still very small and it is difficult for them to create additional communities of practice around the language. Nevertheless, the first initiative has emerged. With every year the number of children educated at different levels through the Witaj framework has increased, which has resulted in new forms and types of Lower Sorbian communities of practice. It is important because the existence of communities of practice linked to the use of a minority language is crucial in the process of acquiring the language and cultural competences of practitioners (Wenger 1998). Firstly, they begin to use the language they are learning in their regular interactions with others thus acquiring a certain fluency in the language. Secondly, they become increasingly interested and engaged in minority culture issues which after their time at school has come to an end can result in their future commitment on behalf of the minority language community (see: Dołowy-Rybińska 2017). Young people who practise a minority language and start to live it in their community surpass the language learners' stage and may become new speakers of this language, for whom a minority language is (one of) tools of everyday communication.

\section{Conclusion}

Education in/of the minority language can give different results according to the cultural and sociolinguistic context in which it functions. This is why one should differentiate between minority language learners and new speaker categories. Both groups are familiarizing themselves with a minority language through an educational context but not everyone learning the language is capable, and willing to use this language after their education comes to an end (or even during their education but outside of school). Being a language learner is thus a step to becoming a minority language new speaker. A new speaker in this sense is a person who has not only achieved some language competence but also has made a conscious decision and a great effort to use the minority language in everyday life. Becoming a new speaker depends on many different factors, among them, the schooling system: Are the teachers well prepared and enthusiastic to teach the language which is at a low level on the linguistic market? Do pupils have the opportunity to use it after lessons end and when they leave the school? Does the school try to counteract existing language ideologies and influence their pupils' language attitudes positively? As we can see all these aspects are not self-evident.

There is another element that can be considered crucial in the minority language appropriation process, this is the existence of some sort of community made up of native speakers - a speech community; of new speakers who meet 
to socialize and to practice their language; or - in the ideal case - a mixed community where native and new speakers communicate together. This role to a certain extent - can be played by different sorts of communities of practice related to the use of a minority language. Learning a language without taking a conscious decision to use it will not change the condition of a minority language that can only survive when it becomes a tool of a communication. Pupils and students in minority language schools should therefore be encouraged, at different levels, using different methods, to become conscious members of a linguistic minority. This function, of transferring cultural and social capital, is together with the language learning, decisive in the process of becoming a new speaker of a language.

\section{REFERENCES}

An Du, Claude. 2000. Histoire d'un interdit. Le breton à l'école. Lannuon: Hor Yezh.

Baker, Colin. 2001. Foundations of Bilingual Education and Bilingualism ( ${ }^{\text {rd }}$ Edition). Clevedon: Multilingual Matters.

Bourdieu, Pierre. 1986. The Forms of Capital, In J. Richardson (ed.), Handbook of Theory and Research for the Sociology of Education. New York: Greenwood: 241-258.

Broudic, Fañch. 2009. Parler breton au XXIe siècle. Le nouveau sondage de TMO-Réions. Brest: Emgleo Breiz.

Broudic, Fañch. 2010. L'enseignement du et en Breton. Brest: Emgleo Breiz.

Broudic, Fañch. 2013. «Langue bretonne: un siècle de mutations ». International Journal of the Sociology of Language 223: 7-21.

Bucholtz, Mary. 2003. "Sociolinguistic Nostalgia and the Authentication of Identity". Journal of Sociolinguistics 7(3): 389-416.

Bucholtz, Mary and Kenneth Hall. 2004. Language and Identity, In: A. Duranti (ed.), A Companion to Linguistic Anthropology. Oxford: Basil Blackwell: 369-394.

Budar, Ludmila and Madlena Norberg. 2006. «Les écoles sorabes après 1990 ». Education et Sociétés Plurilingues 20: 27-38.

Budarjowa, Ludmila. 2014. «Le sorabe à l'école: les sigles Witaj et 2plus». Revue des études slaves 85(2): 303-316.

Chauffin, Fanny. 2015. Diwan, pédagogie et créativité: Approche critique des relations entre pédagogie, créativité et revitalisation de la language bretonne dans les écoles associatives immersives Diwan (PhD thesis, Université Rennes II, France). Available from NNT (2015REN20013). Retrieved from https://tel.archives-ouvertes.fr/tel01144247/file/2015theseChauffinF.pdf (accessed 15 October 2016).

Chauffin, Fanny. 2016. Entre rêves et réalités : les lycéens de Diwan. Revitalisation linguistique en Breton et jeunes locuteurs. In: P. Blanchet and M. Kervran (eds.), Languages minoritaires locales et éducation à la diverité. Paris : L'Harmattan: 103-115.

Costa, James. 2015. "New Speakers, New Language. On Being a Legitimate Speaker of a Minority Language in Provence". International Journal of the Sociology of Language 231: $127-145$. 
Cummins, Jim. 2009. Bilingual and Immersion Programs, In: M.H. Long and C.J. Doughty (eds.), The Handbook of Language Teaching, Oxford, UK: Wiley-Blackwell: 161-181.

Delon, Erwan. 2007. Jeunes Bretons ou "l'identité enchanteresse"? Paris: L'Harmattan.

Dołowy-Rybińska, Nicole. 2011. Języki i kultury mniejszościowe w Europie: Bretończycy, Łużyczanie, Kaszubi. Warszawa: Wydawnictwa Uniwersytetu Warszawskiego.

Dołowy-Rybińska. 2013. "The fest-noz: a way to live Breton culture". Colloquia Humanistica 2: 233-255.

Dołowy-Rybińska, Nicole. 2016. "Language attitudes and community engagement. Diwan - The Breton immersion high school through the eyes of its pupils". Journal of Language, Identity and Education 15(5): 280-292.

Dołowy-Rybińska, Nicole. 2017. "Nikt za nas tego nie zrobi”. Praktyki językowe i kulturowe młodych aktywistach mniejszości językowych Europy. Toruń: Wydawnictwo Naukowe Uniwersytetu Mikołaja Kopernika.

Dołowy-Rybińska, Nicole. (in press). Young people's language activism in Brittany. The case of Diwan immersion High School pupils and graduates. In: M. Hornsby and K. Rosiak (eds.), Eastern European Perspectives on Celtic Studies. Newcastle upon Tyne: Cambridge Scholars Publishing.

Dorian, Nancy C. 1980. "Language Shift in Community and Individual: The Phenomenon of the Laggard Semi-Speaker". International Journal of the Sociology of Language 25: 85-94.

Elégoët, Fanch. 1978. Nous ne savions que le breton et il fallait parler français. Mémoires d'un paysan du Léon. Plabennec: Breizh Hor Bro.

Elle, Ludwig. 2000. Die heutige Situation der sorbischen Sprache und Konzepte zu ihrer Revitalisierung, In: L. Šatava and S. Hose (eds.), Erhaltung, Revitalisierung und Entwicklung von Minderheitensprachen. Theoretische Grundlagen und praktische Maßnahmen. Workshop, Bautzen/Budyšin, 16-17 April 1999. Bautzen/Budyšin: Sorbisches Institut/Serbski institut: 17-21.

Elle, Ludwig. 2010. Sorben - demographische und statistische Aspekte, In: M. T. Vogt, J. Neyer, D. Bingen, and J. Sokol (eds.). Minderheiten als Mehrwert. Frankfurt am Main: Peter Lang: 309-318.

Fishman, Joshua A. 1991. Reversing language shift. Theoretical and empirical foundations of assistance to threatened languages. Clevedon: Multilingual Matters.

Fortune, Tara W. and Diane J. Tedick (eds.). 2008. Pathways to Multilingualism. Evolving Perspectives on Immersion Education. Clevedon: Multilingual Matters.

Garrett, Peter. 2010. Attitudes to language. Cambridge: Cambridge University Press.

Garrett Peter, Nikolas Coupland and Angie Williams. 2003. Investigating Language Attitudes: Social Meanings of Dialect, Ethnicity and Performance. Cardiff: University of Wales Press.

Goalabre, Fabienne. 2011. "The choice of bilingual schools in language shift situation in Brittany and in the Western Isles of Scotland". Proceedings of the Harvard Celtic Colloquium 31: 118-136.

Harris John and Lelia Murtagh. 1999. Teaching and learning Irish in primary schools. Dublin: Institiúid Teangeolaíochta Éireann.

Heller, Monica. 1999. Heated language in a cold climate. In: J. Blommaert (ed.). Language Ideological Debates. Berlin: Mouton de Gruyter: 369-371.

Hinton, Leanne. 2001. Teaching methods. In Leanne Hinton and Ken Hale (eds.). The green book of language revitalization in practice. San Diego, CA: Academic Press, 179-189. 
Hornsby, Michael. 2005. "Néo-breton and questions of authenticity". Estudios De Sociolingüistica 6(2): 191-218.

Hornsby, Michael. 2015. Revitalizing Minority Languages. New Speakers of Breton, Yiddish and Lemko. New-York: Palgrave Macmillan.

McDonald, Maryon. 1989. “We are not French!” Language, culture, and identity in Brittany.. New York: Routledge.

Mercator European Research Centre on Multilingualism and Language Learning. 2016. Sorbian: The Sorbian language in education in Germany. ( $2^{\text {nd }}$ Edition).

Neumann, Ines. 2014. "Weil es eine sprechenswerte Sprache ist. ” Einstellungen von Schülern des Niedersorbischen Gymnasiums Cottbus zur sorbischen Sprache und Kultur. Bautzen: Domowina-Verlag.

Nicolas, Michel. 2001. Bretagne, un destin européen ou la Bretagne et le fédéralisme en Europe. Rennes: Presses Universitaires de Rennes.

Norberg, Madlena. 2010. WITAJ in Brandenburg. Stand und Weiterentwicklung eines erfolgreichen bilingualen Sprachprogramms. Uberarbeitete Konzeption. Cottbus: Rěcny centrum WITAJ-Sprachzentrum.

Norbergowa, Madlena. 1997. "Rěcna změna w Dolnej Łužycy a jeje faktory”. Rozhlad 47: 202-205.

O'Rourke, Bernadette. 2011. "Whose Language is it? Struggles for Language ownership in an Irish Language Classroom". Journal of Language, Identity, and Education 10: 327-345.

O'Rourke Bernadette, Ramallo Fernando and Joan Pujolar. 2015. "New Speakers of Minority Languages: The Challenging Opportunity". International Journal of the Sociology of Language 231: 1-20.

Pech, Edmund. 2001. "The Sorbian school system in Germany 1945-2000”, Education et Sociétés Plurilingues 10: 39-48.

Pentecouteau, Hugues. 2002. Devenir bretonnant. Découvertes, apprentissages et réappropriations d'une langue. Rennes: Presses Universitaires de Rennes.

Perazzi, Jean-Charles. 1998. Diwan, vingt ans d'enthousiasme, de doute et d'espoir. Spézet, France: Coop Breizh.

Marti, Roland. 2014. "Haut- et bas-sorabe: une cohabitation linguistique difficile ». Revue des études slaves 85(2): 215-233.

Sallabank, Julia. 2013. Attitudes to Endangered Languages: Identities and Policies. Cambridge: Cambridge University Press.

Schieffelin Bambi B., Woolard Kathryn A. and Paul V. Kroskrity (eds.). 1998. Language Ideologies: Practice and Theory. New York: Oxford University Press.

Skutnabb-Kangas, Tove. 2000. Linguistic Genocide in Education - or Worldwide Diversity and Human Rights? New Jersey - Londyn: Taylor and Francis.

Spiess, Gunter. 1994. "Dolnoserby a Gornoserby”, Rozhlad 44: 280-283.

Steenwijk, Han. 1999. "Někotare wuslědki sociolinguistiskego napšašowania w Dolnej Łužycy". Rozhlad 49: 442-447.

Vetter, Eva. 2013. "Teaching Languages for a Multilingual Europe - Minority Schools as Examples of Best Practice? The Breton Experience of Diwan”, International Journal of the Sociology of Language 223: 153-170.

Wenger, Etienne. 1998. Communities of Practice. Learning, Meaning, and Identity, Cambridge: Cambridge University Press.

Wenger-Trayner, Etienne and Beverly Wenger-Trayner. 2015. Communities of practice. A brief introduction retrieved from: http://wenger-trayner.com/wp-content/uploads/2015/04/ 07-Brief-introduction-to-communities-of-practice.pdf (assessed 19 October 2016). 
Woolard, Kathryn. 2008. Language and Identity Choice in Catalonia: The Interplay of Contrasting Ideologies of Linguistic Authority, In: K. Süselbeck, U. Mühlschlegel and P. Masson (eds.), Lengua, nación e identidad. La regulación del plurilingüismo en España y América Latina. Frankfurt am Main: Vervuert; Madrid: Iberoamericana: 303-323.

Woolard, Kathryn. 2011. "Is there linguistic life after high school? Longitudinal changes in the bilingual repertoire in metropolitan Barcelona”. Language in Society 40(5): 617-648.

Zakar, Viktor. 2016. "Góźby za wužywanje dolnoserbšćiny we wólnem casu a pórucenja pólěpšenjupóbitowanjow”. Serbska Šula 3: 66-70.

\section{FIGURES}

Figure 1: Lusatia in Germany (map)

Figure 2: Brittany in France (map) 